\title{
EU AS A HUMAN RIGHTS ACTOR?'
}

\author{
Lucia Mokrá, Kristína Janková \\ Comenius University in Bratislava, Faculty of Social and Economic Sciences
}

\begin{abstract}
The human rights are fundamental principle of the European Union law, which should be observed in adoption of legislative rules as well as in implementation practice. The EU had been initially founded as the economic cooperation project and an ambition to establish cooperation between its member states also in political agenda became more visible especially since the Lisbon Treaty, by which the position of EU in area of external relations was strengthened. The paper analyses position of the European Union when promoting and protecting human rights in external relations. As there exist several tools and mechanisms EU may use in implementation of human rights policy, we analyze the role of the EU in relation to the application of human rights in foreign policy as stated in Article 2 and Article 6 of the Treaty on European Union.
\end{abstract}

Keywords: human rights, European Union, external relations, Copenhagen criteria

\section{INTRODUCTION}

The European Union, that since the adoption of the Lisbon Treaty has acquired legal personality, has strengthened its position in the economic market, and has also outlined plans for a stronger position in international relations. During the development the EU has created an idea of a European identity based on civilian power, ${ }^{2}$ normative power ${ }^{3}$ or superpower. ${ }^{4}$ However, the ontological debate on defining the EU can keep forever, so the researchers also took deontological position and looked rather what the EU does in order to allow a comparison of statements and actions - words and deeds. ${ }^{5}$ In this respect, therefore, it is important to understand what the main principles of the EU are and how these are implemented by the EU not only in its internal policies but also in its external relations. On the basis of Art. 2 TEU, the EU is committed to the values of human dignity, freedom, democracy, the rule of law and respect for human rights, including minority rights. At the same time Art. 2 highlighted the key role of pluralism, the principle of nondiscrimination, tolerance, justice, solidarity, and gender equality. The Union has thus gradually established its role in of the international scenario ${ }^{6}$ whether planned (economic giant) or more

This work was supported by the Slovak Research and Development Agency under the contract No. APVV-16-0540.

2 DUCHÊNE, F.: The European Community and the Uncertainties of Interdependence. In: KOHNSTAMM, M. - HAGER, W.: A Nation Writ Large? Foreign-Policy Problems before the European Community. London: Macmillan, 1973, pp. 1920; SMITH, K. E.: Still 'civilian power EU'? Working paper 1. Oslo: European Foreign Policy Unit, 2005. Available at: www.arena.uio.no/cidel/WorkshopOsloSecurity/ (accessed on $5^{\text {th }}$ November 2018).

3 MANNERS, I.: Normative Power Europe: A Contradiction in Terms? In: Journal of Common Market Studies, 40, 2002, 2, pp. 235-58; MANNERS, I.: Normative Ethics of the European Union. In: International Affairs, 84, 2008, 1, pp. 45-60. McCORMICK, J.: The European Superpower. Basingstoke: Palgrave Macmillan, 2007.

5 BINDI, F.: The Foreign Policy of the European Union. Washington: The Brookings Institution, 2010.

6 ELGSTRÖM, O. - SMITH, M.: The European Union's Role in International Politics. Concepts and Analysis. New York: Routledge, 2006; AGGESTAM, L.: A European Foreign Policy? Role Conceptions and the Politics of Identity in Britain, 
or less randomly (human rights defenders, developer). These tasks (roles) are key to the research question in this article.

The EU as an actor in international relations ${ }^{7}$ has observation status at the United Nations, a comprehensive external policies and institutions that are, however, often criticized for a lack of coherence and consistency. EU external action includes a number of specific policies (international trade, development and humanitarian aid, security and defense policy, energy policy, diplomacy, migration, etc.). The EU added especially in relation to efficiency of Lisbon Treaty to its agenda human rights as the one of the EU fundamental principle and try to actively contribute to support and promotion of human rights worldwide. While its particular focus is mainly connected with the economic and diplomatic relations, human rights remain one of the priorities in EU foreign policy.

As the EU itself declares, it has made a positive and constructive contribution to the international relations and development of the 2030 Agenda for Sustainable Development. The 2030 Agenda emphasizes also issues such as effective institutions, good governance, the rule of law and peaceful societies, including promotion and protection of human rights (which are also stated as principles in Article 2 of TEU).

In this sense, research regarding the $\mathrm{EU}$ in international regimes focuses often on the principle of "effective multilateralism", which is one of the core principles in the EU external relations as a part of the desired comprehensive approach. ${ }^{9}$ The further analysis focuses on the EU behavior in human rights regime. Despite the fact that the human rights regime can be defined as relatively powerful regime, the $\mathrm{EU}$ in this case has not downloaded the regime as such but created its own through Art. 2 and Art. 6 TEU.

According to this, we focus on research question, whether the EU may emerge as human rights actor in world politics? In this sense we analyze the position of the EU in human rights protection and promotion in its external relations, by establishing the legal framework and using its own system of instruments and implementation policies.

\section{EU FOREIGN POLICY AND HUMAN RIGHTS}

In order to grasp the EU action in its external relation related to human rights and to explore whether the $\mathrm{EU}$ is a significant actor, we use the concept of actorness, that allows us to identify the features and specialties of the $\mathrm{EU}$ as a human rights actor in international relations.

Concept of actorness has been subject to scholars mainly from the 70s, as the EU started to build its international position through the economic cooperation. Sjöstedt ${ }^{10}$ raised the debate about actor

France and Germany. Doctoral dissertation. Stockholm: University of Stockholm, 2004; BREUNING, M.: Role theory research in international relations. State of art and blind spots. In: HARNISCH, C. F. S.: Role Theory in International Relations. Approaches and analyses. London and New York: Routledge, 2011, pp. 16-33.

7 BRETHERTON, C. V.: The European Union as a Global Actor. London: Routledge, 1999; GINSBERG, R. H.: The European Union in International Politics. Baptism by Fire. Boston, USA: Rowman \& Littlefield Publishers, 2001.

8 E.g. ELGSTRÖM, O. - SMITH, M.: The European Union's Role in International Politics. Concepts and Analysis. New York: Routledge, 2006.

9 MOGHERINI, F.: Shared Vision, Common Action: A Stronger Europe. The Global Strategy for the European Union's Foreign and Security Policy, 2016. Available at: https://eeas.europa.eu/archives/docs/top_stories/pdf/eugs_review_ web.pdf (accessed on $5^{\text {th }}$ November 2018).

10 SJÖSTEDT, G.: The external role of the European Community. Hamshire: Saxon House, 1977. 
capabilities that were determined by the autonomy in the decisions and available capabilities to act. The debate on actorness, however, boosted especially after the adoption of Maastricht treaty and creation of three pillar system. ${ }^{11}$ The initial conceptualization involved several criteria the EU has to fulfill or reach in order to be considered an actor. These criteria evolved from cohesion, autonomy, authority and recognition, ${ }^{12}$ to shared values and principles, domestic legitimacy, consistent and coherent policies and availability of and capacity to utilize policy instruments. ${ }^{13}$ Later on, due to continual progress in EU integration, including enlargement and other areas of external relations, the conceptualization shifted to more constructivist, and thus identity oriented approaches arguing that the EU actorness is built on the self-perception of the EU, recognition of the EU by other actors, international presence, institutionalization and instruments and procedures that enable the conduct of external relations. ${ }^{14}$ The constructivist approach was adopted also in the 2006 updated conceptualization by Bretherton and Vogler ${ }^{15}$ based on three criteria - opportunity, presence and capability. For our interdisciplinary approach, however, Richard's and Van Hamme's approach served as an inspiration. ${ }^{16}$ They selected three criteria that are extremely relevant for a geographical analysis opportunity, consistency, and effectiveness. ${ }^{17}$

In our analysis, we apply their logic and selected criteria in order to conduct legal analysis of the EU actorness, where the effects of Article 2, Article 6 and Article 21 of the Treaty on European Union are explored. For the legal analysis, a) institutionalization, b) instruments and procedures enabling the conduct of external relations, and c) consistency and coherence are taken into account.

Under institutionalization, we understand the establishment of policy within the EU structures with clear decision-making procedures. In this respect the legal framework is established by Lisbon treaty and the Article 2, Article 6 and Article 21 of the Treaty on European Union as the fundamental basis for extended scope of the EU external action on human rights and democracy, upon which the EU can build its role as the human rights defender and human rights promoter beyond its borders. Especially the text of Article 21 of the Treaty on European Union has reaffirmed the EU's determination to promote human rights and democracy through all its external actions. The adopted Joint Communication of the European Commission and EU High Representative for Foreign Affairs and Security Policy 'Human Rights and democracy at the heart of EU external action - Towards

11 See JUPILLE, J. - CAPORASO, J.: States, Agency and Rules: the European Union in Global Environmental Politics. In: RHODES, C. (ed.): The European Union in the World Community. Boulder, CO: Lynne Rienner, 1998, pp. 213-229; BRETHERTON, CH. - VOGLER, J.: The European Union as Global Actor. London: Routledge, 1999; WUNDERLICH, U.: The EU - A post-Westphalian actor in a neo-Westphalian world? Paper for presentation at the UACES Annual/Research Conference University of Edinburgh, 1-3 September 2008.

12 JUPILLE, J. - CAPORASO, J.: States, Agency and Rules: the European Union in Global Environmental Politics, op. cit.

13 BRETHERTON, CH. - VOGLER, J.: The European Union as Global Actor, op. cit.

14 WUNDERLICH, U.: The EU - A post-Westphalian actor in a neo-Westphalian world?, op. cit.

15 BRETHERTON, CH. - VOGLER, J.: The European Union as Global Actor (2 ${ }^{\text {nd }}$ edition). London: Routledge, 2006

16 ALLEN, D. - SMITH, M.: Western Europe's presence in the contemporary international arena. In: Review of International Studies, 16, 1990, 1, pp. 19-37.

NIEMANN, A. - BRETHERTON, Ch.: Introduction: EU external policy at the crossroads. In: International Relations, Vol. 27, 2013, No. 3, pp. 261-275. Available at: https://international.politics.uni-mainz.de/files/2012/10/Niemann-andBretherton_Special-edition_introduction_final.pdf (accessed on $5^{\text {th }}$ November 2018).

17 RICHARD, Y. - VAN HAMME, G.: L'Union européenne, un acteur des relations internationales: Étude géographique de l'actorness européenne. In : L’Espace géographique, vol. 42, 2013, 1, pp. 15-30. Available at: https://www.cairn.info/ revue-espace-geographique-2013-1-page-15.htm (accessed on $5^{\text {th }}$ November 2018). 
a more effective approach, ${ }^{18}$ is the key contribution to the development of the EU position and EU strategy in area of human rights in external relations. This communication provides the framework to promote human rights in particular areas of EU external relations (e.g. in trade, democracy, international cooperation, neighborhood policy).

Under instruments and procedures, the paper focuses on the implementation of provision laid down in Article 2, Article 6 and Article 21 into concrete tools and mechanism the EU has developed over time, including the EU Special Representative for Human Rights (financial tools and competences) and EU Instrument for Democracy and Human Rights. Within these instruments and procedures that the EU possesses, we also look at different type of actions. There generally exist three types of actions the $\mathrm{EU}^{19}$ applies in its human rights agenda:

a) support to achievement of human rights standards through financed programs,

b) asymmetrical interdependence (political conditionality),

c) using of sanctions, so called ethical dimension.

The first type of action refers to financial programs under the EU Special Representative for Human Rights and other instruments. The second one, political conditionality, is used as the part of the Copenhagen criteria in the enlargement process and as it is only one part of the three different areas of accession criteria (territorial criteria, democracy criteria - including human rights, economic criteria), we consider it too wide for the proper evaluation within our research focus. The third one sanction mechanism the EU in relation to countries and partners in external relations has not yet been used, only in connection with economic sanctions. This interdependence may influence the proper evaluation of the EU role as the human rights actor.

As for consistency and coherence, we observe the changes in the proposed and adopted actions. This is analyzed in the EU Action Plans on Democracy and Human Rights, their reviews and subsequent Human Rights Report from 2015 to 2017 (as following actual EU Action Plan for 20152019). Consistency and coherence are understood in the sense that the EU is continually working with same priority agenda. These criteria have been studies and evaluated since the adoption of the Maastricht Treaty in 1993, when the foreign policy, mainly consisting of enlargement policy, became institutionalized.

\subsection{Strategic framework on human rights and democracy}

EU's Strategic Framework and Action Plan on Human Rights and Democracy was adopted by the Council on 25 June $2012^{20}$ as the framework document setting priorities in area of human rights and democracy in internal and external policies of the EU. It is focused mainly on human rights, democracy and rule of law, as those are set also as common values and accession criteria for EU membership (so-called Copenhagen criteria).

18 Joint Communication of the European Commission and EU High Representative for Foreign Affairs and Security Policy 'Human Rights and democracy at the heart of EU external action - Towards a more effective approach', COM(2011) 886 final, 12. 12. 2011. Available at: https://eur-lex.europa.eu/LexUriServ/LexUriServ.do?uri=COM:2011:0886:FIN:EN:PDF (accessed on $5^{\text {th }}$ November 2018).

19 According SEDELMEIER, U.: The EU's role as a promoter of human rights and democracy: enlargement policy practice and role formation. In: ELGSTROM, O. - SMITH, M. (eds.): The European Union's Role in International Politics: Concepts and Analysis. Routledge/ECPR studies in European political science. London: Routledge, 2006, pp. 118-135.

20 EU's Strategic Framework and Action Plan on Human Rights and Democracy. Available at: https://www.consilium.europa.eu/uedocs/cms_data/docs/pressdata/EN/foraff/131181.pdf (accessed on $5^{\text {th }}$ November 2018). 
According to Strategic framework on human rights, human rights are universally applicable legal norms. The common values as sustainable peace, development and prosperity of people are possible to be achieved only when there are respected human rights, democracy and rule of law. As EU declared in the framework, "the EU is aware of these challenges and determined to strengthen its efforts to ensure that human rights are realized for all. The EU will continue to throw its full weight behind advocates of liberty, democracy and human rights throughout the world."21 In several following provisions, the $\mathrm{EU}$ is to confirm its interest to contribute to promotion and protection of all human rights and also calls on its member states to implement human rights as set in the Universal Declaration of Human Rights and international human rights treaties. Particularly the Strategic framework was adopted to set priorities in area of external relations, reflecting this goal as set in article 21 of the Treaty on European Union.

Stated coherent objective of the EU in area of human rights, democracy and rule of law is to be applied in all aspects of external relations. "The EU will step up its efforts to promote human rights, democracy and the rule of law across all aspects of external action. It will strengthen its capability and mechanisms for early warning and prevention of crises liable to entail human rights violations. It will deepen its cooperation with partner countries, international organizations and civil society, and build new partnerships to adapt to changing circumstances. The EU will strengthen its work with partners worldwide to support democracy, notably the development of genuine and credible electoral processes and representative and transparent democratic institutions at the service of the citizen."22

As set in the Strategic framework on human rights and democracy, the EU institutions already play the leading role in the promotion of human rights. From the point of the actorness, the stated necessary cooperation between European Parliament, the Council, the Member States, the European Commission and the EEAS is condition sine qua non for implementation and improvement of the human rights in practice. The $\mathrm{EU}$ in this particular agenda want to cooperate with other international actors, as UN (United Nations General Assembly, the UN Human Rights Council and the International Labour Organisation, UN Office of the High Commissioner for Human Rights, as well as of the treaty monitoring bodies and UN Special Procedures and UN Human Rights Council), Council of Europe and OSCE, African Union, ASEAN, SAARC, the Organisation of American States, the Arab League, the Organisation of Islamic Cooperation and the Pacific Islands Forum. Once considering number of international stakeholders in area of human rights as mentioned, the EU position as not originally human rights organisation, face the different implementation challenges.

\subsection{Action Plans on Human Rights and Democracy}

Regarding to implementation of the EU Strategic Framework on Human Rights and Democracy and with the aim to effectively respond to new challenges, there are prepared Action plans. The first action plan was adopted together with the Strategic framework on human rights and democracy for period of one and a half year, by the end of 2014. The next action plan was adopted for the period 2015-2019. The latter builds on the results and achievements of the former and focuses mainly on issues that were not tackled sufficiently and left gap for further EU actions.

21 Ibid.

22 Ibid. 
The Action Plan 2012-2014 consists of seven chapters, with 36 goals and 97 actions altogether, broadly focused on following areas: 1. Human rights and democracy throughout EU policy; 2. Promoting the universality of human rights; 3 . Pursuing coherent policy objectives; 4 . Human rights in all EU external policies; 5. Implementing EU priorities on human rights; 6. Working with bilateral partners; 7. Working through multilateral institutions. ${ }^{23}$

This action plan can be characterized as a starting point for the EU human rights and democracy external action. The goals include endurance of support, consolidation, intensification, promotion, development, establishment and inclusion of new tools, mechanisms and methods in the area of human rights and democracy. From the document it is clear that the EU addresses the lacking comprehensive human rights policy in its external action and realizes serious problems related to double standards and inconsistencies internally as well as externally. The broadest chapter, titled Implementing EU priorities on human rights consists of 15 goals including abolition of death penalty, support for Human Rights Defenders, protection of women's rights or compliance with international humanitarian law. The assessment of the results was stressing significant progress in several areas including the establishment of Brussels-based Council Working Group on Human Rights (COHOM); adoption of guidelines on various issues including LGBTI rights; basic methodology for rights-based-approach to development. One of the core successes was adoption on National Human Rights Strategies across the world. The action plan also established training programs for the EU staff in the field of human rights issues and gender equality. The European Commission, however, identified several areas where more needs to be done stressing especially Economic, Social and Cultural rights; respect and promotion of human rights and international humanitarian law in crises and conflicts; violation of non-discrimination, mainly against women, children, disabled persons and LGBTI and members of religious minorities; fight against torture and ill-treatment. Special attention was paid to increase the coherence of EU policies from a human rights point of view. These were later included in the Action Plan for period 2015-2019.

Action Plan on Human Rights and Democracy for period 2015-2019 titled "Keeping human rights at the heart of the EU agenda" consist of five broad areas: 1. Boosting the ownership of local actors; 2. Addressing key human rights challenges; 3 . Ensuring a comprehensive HR approach to conflict and crises; 4 . Fostering better coherence and consistency; and 5. Deepening the effectiveness and results culture in Human Rights and democracy. The areas include 34 goals and 113 actions. ${ }^{24}$

Despite the different chapter titles, both action plans share majority of goals; the actions differ, but mainly because something has been already done. The action plan for 2015-2019 then continues with what the previous one began, or, in areas where there has not been much progress set different starting activities. The goals and action from Chapter $\mathrm{V}$ of previous action plan are identical with those in 2015-2019 Action plan. This plan also requires systematic reporting on assessment of the applied and implemented tools and mechanisms through newly developed or improved methods of evaluation.

The plan made significant progress in identifying the root causes of current global phenomena, such as migration and it also includes clause on the coherence in application of human rights clauses that are included in the EU international agreements. On the other hand, in the area of HR approach

23 EU Action Plan on Human Rights and Democracy 2012-2014. Available at: https://www.consilium.europa.eu/uedocs/ cms_data/docs/pressdata/EN/foraff/131181.pdf (accessed on $5^{\text {th }}$ November 2018).

24 EU Action Plan on Human Rights and Democracy 2015-2019. Available at: https://ec.europa.eu/anti-trafficking/sites/ antitrafficking/files/action-plan-on-human-rights-and-democracy-2015-2019_en.pdf (accessed on $5^{\text {th }}$ November 2018). 
to conflict and crisis, even more problems were detected, and more goals stated. This was identified also in the mid-term review of the action plan as Commission argues that "the Action Plan could be most effective if fewer actions and commitments were prioritized more selectively"25 as well as that the "work on a comprehensive Human Rights approach to conflicts and crises (Chapter 3) will remain a priority until $2019 .{ }^{26}$ This area lacks systematic reporting mechanism. The Commission again underlines that compliance with human rights standards and with international humanitarian documents still "remains priority." ${ }^{27}$ In other areas, the mid-term review emphasizes the significant EU efforts in relation to support of local ownership through human rights dialogues, various projects and financial assistance; in Chapter II focused on human rights challenges, the review welcomes the update of Guidelines on the Promotion and Protection of the Rights of the Child, sees much more potential in using the adopted measures and tools including the National Human Rights Plans. Chapter IV is still one of those that opened a chapter in a much different context than was previously tackled (migration and refugees) and thus needs more time to implement the goals and deepen cooperation with other actors. Public diplomacy and better communication remain a challenge as well, despite several efforts of the EU, mainly through \#EU4HumanRights campaign.

The Action Plan contributed to more comprehensive approach of the EU to the human rights in its external action. However, there are clear signs that the EU is still developing the most appropriate method of achieving the goals set in the plans. Even more problematic is that EU is finding more and more goals it wishes to achieve that may decrease the quality of implementation and achievement of these goals, as there are so many of them covering too many issues even for such a bureaucracy as the EU. Despite the international environment is providing the EU many opportunities to conduct actions, the EU should prioritize between them as too many of them are then executed in the form of oral support or small-session with no effects.

\subsection{Human Rights Tools and Institutions}

The EU had elaborated its own system of tools and institutions for active implementation of the human rights principle in EUFP. There are three of them institutionalized in the form of the personal capacity (EU Special Representative for Human Rights), financial capacity (European instrument for democracy and human rights) and of administrative capacity (in the form of periodical reviews Human Rights reports).

\subsubsection{EU Special Representative for Human Rights}

The position of the EU special representatives is connected with the Lisbon Treaty itself and in the area of human rights it follows adoption of EU's Strategic Framework and Action Plan on Human Rights and Democracy.

The very first EU special representative was appointed for agenda of human rights in July 25, 2012, according to the Council decision. ${ }^{28}$ The role of the special representative is to enhance the

25 Council Conclusions on the mid-term review of the Action Plan on Human Rights and Democracy 2015-2019, p. 22. Available at: https://www.consilium.europa.eu/media/21512/st12815en17-cc.pdf (accessed on $5^{\text {th }}$ November 2018).

26 Ibid.

27 Ibid., p. 23.

28 Council Decision 2012/440/CFSP of 25 July 2012 appointing the European Union Special Representative for Human Rights, OJ L 200, 27. 7. 2012, p. 21-23. Available at: http://data.europa.eu/eli/dec/2012/440/oj (accessed on $5^{\text {th }}$ November 2018). 
effectiveness and visibility of EU human rights policy. He has a broad, flexible mandate, giving him the ability to adapt to circumstances, and he works closely with the European External Action Service, which provides him with full support. "The EU special representative for human rights should reflect EU human rights policy and cover areas that include strengthening democracy, international justice, humanitarian law, abolition of the death penalty, freedom of expression, gender issues and children and armed conflict. The EUSR for Human Rights will be expected to engage with the UN, chair high-level human rights dialogues and lead consultations with third countries on human rights issues." 29

As stated in Article 2 of the Council decision, the objective of the work of the EUSR for Human Rights should follow the provisions of the Treaties, the Charter of Fundamental Rights of the European Union as well as the EU Strategic Framework on Human Rights and Democracy and the EU Action Plan on Human Rights and Democracy. The concrete objectives are then identified as:

“(a) enhancing the Union's effectiveness, presence and visibility in protecting and promoting human rights, notably by deepening Union cooperation and political dialogue with third countries, relevant partners, business, civil society and international and regional organisations and through action in relevant international fora;

(b) enhancing the Union's contribution to the strengthening of democracy and institution building, the rule of law, good governance, respect for human rights and fundamental freedoms worldwide;

(c) improving the coherence of Union action on human rights and the integration of human rights in all areas of the Union's external action."30

Such a mandate was extended by the Council decision 2014/385/CFSP of 23 June 2014. ${ }^{31}$ However, the work of the EUSR for Human Rights had been exercised for two years by then; the Council Decision extended only the working period of EUSR, there was not involved matter-of-fact competence extension.

This pure formalistic approach without any change in competences, reflecting findings, evaluations and changes of the social environment, current challenges to human rights as stated in the particular Action plans are not reflected at all. Council decisions were later adopted in $2015,{ }^{32} 2016^{33}$ and $2017,{ }^{34}$ each for period of 24 months. The legal development is not following the state of art and the general mandate of the EUSC for human rights is more or less copy-pasted in Council decisions.

29 DEMPSEY, J.: Will an EU Special Representative for Human Rights Make a Difference? Available at: https://carnegieeurope.eu/strategiceurope $/ 48818$ (accessed on $5^{\text {th }}$ November 2018).

30 Article 2, Council Decision 2012/440/CFSP of 25 July 2012 appointing the European Union Special Representative for Human Rights, OJ L 200, 27. 7. 2012, p. 21-23. Available at: http://data.europa.eu/eli/dec/2012/440/oj (accessed on $5^{\text {th }}$ November 2018).

31 Council Decision 2014/385/CFSP extending the mandate of the European Union Special Representative for Human Rights, OJ L 183, 24. 6. 2014, p. 66-69. Available at: http://data.europa.eu/eli/dec/2014/385/oj (accessed on $5^{\text {th }}$ November 2018).

32 Council Decision (CFSP) 2015/260 of 17 February 2015 extending the mandate of the European Union Special Representative for Human Rights. OJ L 43, 18. 2. 2015, p. 29-32.

33 Council Decision (CFSP) 2016/208 of 15 February 2016 amending Decision (CFSP) 2015/260 extending the mandate of the European Union Special Representative for Human Rights IO L 39, 16. 2. 2016, lch. 47-47. Available at: http://data. europa.eu/eli/dec/2016/208/oj (accessed on $5^{\text {th }}$ November 2018).

34 Council Decision (CFSP) 2017/346 of 27 February 2017 extending the mandate of the European Union Special Representative for Human Rights. OJ L 50, 28. 2. 2017, p. 66-69. Available at: http://data.europa.eu/eli/dec/2017/346/oj (accessed on $5^{\text {th }}$ November 2018). 
There is only one exception, which may be interpreted as the interest of the EU to act as human rights actor in foreign policy. Such issue is allocation of financial support to the work of the EUSC for human rights, as follows:

Table No. 1: Financial allocation for work of EUSR for Human rights

\begin{tabular}{|l|c|}
\hline \multicolumn{1}{|c|}{ Period of finances allocation } & Allocated amount from EU budget \\
\hline $\begin{array}{l}\text { 25 July 2012 to 30 June 2013 } \\
\text { (mandate from 25 July 2012 - 30 June 2014) }\end{array}$ & 712.500 EUR \\
\hline 1 July 2014 to 28 February 2015 & 550.000 EUR \\
\hline 1 March 2015 to 29 February 2016 & 788.000 EUR \\
\hline 1 March 2016 to 28 February 2017 & 825.000 EUR \\
\hline 1 March 2017 to 28 February 2018 & 860.000 EUR \\
\hline 1 March 2018 to 28 February 2019 & 894.178 EUR \\
\hline
\end{tabular}

Source: Council Decisions ${ }^{35}$

The amount is increased on the annual basis, and since 2015 it constantly rose. This on one side confirms EU intention to use the financial programs for promotion of human rights in the foreign policy, on the other side this information is not absolute, while not containing the budget of other EU special representatives, who are also operating in area of human rights as integral part of its territorial mandate (e.g. Georgia, Kosovo, Afghanistan etc.).

\subsubsection{European instrument for democracy and human rights}

The European instrument for democracy and human rights (hereinafter as EIDHR) was established on the basis of the European Parliament and the Council Regulation ${ }^{36}$ in 2014, replacing the previous instruments (EIDHR 2007 - 2013 and the European Initiative for Democracy and Human Rights 2000 - 2006).

As such, it is a thematic funding instrument for EU external action aiming to support projects in the area of human rights, fundamental freedoms and democracy in non-EU countries. This instrument is designed to support civil society to become an effective force for political reform and defense of human rights. As stated in the Regulation, "within the framework of the principles and objectives of the Union's external action, the promotion of human rights, democracy, the rule of law and good governance, and of inclusive and sustainable growth, constitute two basic pillars of the Union's development policy. A commitment to respect, promote and protect human rights and democratic principles is an essential element of the Union's contractual relations with third countries." 37

The human rights are in the center of the EIDHR, while reflecting connected strategic documents and mainly the initial one, Council Conclusions of 18 November 2009 on democracy support

35 Council Decisions: 2012/440, 2014/385, 2015/260, 2016/2018, 2017/346, 2018/225 as quoted above.

36 Regulation (EU) No 235/2014 of the European Parliament and of the Council of 11 March 2014 establishing a financing instrument for democracy and human rights worldwide. OJ L 77, 15. 3. 2014, p. 85-94.

37 Article 5, Regulation (EU) No 235/2014 of the European Parliament and of the Council of 11 March 2014 establishing a financing instrument for democracy and human rights worldwide. OJ L 77, 15. 3. 2014, p. 85-94. 
in the EU's external relations. ${ }^{38}$ In this one, there is framed the fundamental human rights approach of the EU in its external relations: "The fundamental freedoms of thought, conscience and religion or belief, expression, assembly and association are the preconditions for political pluralism, democratic process and an open society, whereas democratic control, domestic accountability and the separation of powers are essential to sustain an independent judiciary and the rule of law which in turn are required for effective protection of human rights." 39

According to this, EIDHR is a specific tool within the EU toolbox, which provides possibility to cooperate directly with human rights experts and activists, civil society organisations and other non-state actors. It may then refer to human rights topic without necessary political or governmental background, such as death penalty, freedom of expression, protection of journalists, discrimination of vulnerable social and ethnical groups etc. For the period of 2014-2020 the EIDHR has set 5 specific objectives:

1. Objective 1 - Support to human rights and human rights defenders in situations where they are most at risk.

2. Objective 2 - Support to other priorities of the Union in the field of human rights

3. Objective 3 - Support to democracy.

4. Objective 4 - EU Election Observation Missions (EOMs)

5. Objective 5 - Support to targeted key actors and processes, including international and regional human rights instruments and mechanisms. ${ }^{40}$

As such, the EU supports different types of actions within EIDHR with financial support. The allocated budget for EIDHR in the period of 2014-2020 is 1.332 .75 million EUR, representing almost $21 \%$ increase to previous multi-financial framework 2007-2013 budget.

\subsubsection{Human Rights report}

The evaluation of the Human Rights policy and the role and its exercise by the EU as one priority of the European Union's external action, is based on the annual report on human rights and democracy, issued by the Council. The reports assess progress in particular areas of the Action Plans and provide rich source of information on the EU actions in external relations connected with human rights.

The 2015 EU Annual Report on Human Rights and Democracy in the World was the first one in the newly reported period according to Action plan 2015 - 2019. The very first report was adopted in two steps - the thematic part was adopted on 20 June 2016, while country and regional issues part was adopted on 20 September 2016. As proclaimed, also within new operational period according to Action plan, the EU continued defending and promoting human rights, rule of law and humanrights based approach in the inclusive and democratic societies of the world. In 2015, the work of EU and its actions were especially challenged by number of instabilities in neighborhood and strategic regions and conflicts (e.g. Middle East, part of Asia, Africa) and also by serious human rights violations and attacks on civilians and vulnerable groups. The voice of the EU was presented mainly

38 Council Conclusions of 18 November 2009 on democracy support in the EU's external relations. Available at: http:// register.consilium.europa.eu/doc/srv?l=EN \& f=ST\%2016081\%202009\%20INIT (accessed on 5 ${ }^{\text {th }}$ November 2018).

39 Ibid.

40 Annex 1, Regulation (EU) No 235/2014 of the European Parliament and of the Council of 11 March 2014 establishing a financing instrument for democracy and human rights worldwide. OJ L 77, 15. 3. 2014, p. 93. 
through adopted Joint Communication 'Keeping Human Rights at the heart of the EU Agenda". ${ }^{41}$ One of the key tasks is the support of human rights defenders and civil society organizations. The EU through different tools used to raise "EU's effectiveness and visibility as a preeminent world actor on human rights and to advocate for key EU priorities, including freedom of expression and association, women's and children's rights, the fight against torture, non-discrimination, the abolition of the death penalty, economic, social and cultural rights, business and human rights and promoting accountability for human rights violations". ${ }^{42}$

The EU Annual Report on Human Rights and Democracy in the World in 2016 was adopted by Council on 16 October 2017. The EU itself considered year 2016 as the year important for human rights and democracy, when facing different humanitarian and political challenges. It was also important year when re-evaluating the importance of civil society in area of human rights protection. As Federica Mogherini said, "Civil society organizations and human rights defenders in general, are a pillar of every well-functioning state, and key players to improve the situation of human rights across the globe." ${ }^{43}$ In 2016 also other strategic EU instruments were adopted, such as EU human rights guidelines - " 11 sets of guidelines set out priority areas for external action. The guidelines are not legally binding, but because they have been adopted at ministerial level, they represent a strong political signal that they are priorities for the Union." ${ }^{\text {"4 }}$ There had started also elaboration of $\mathrm{Hu}$ man Rights and Democracy Country Strategies, based on analysis of the human rights situation in the concrete countries. Strategies should cover period of 2016 - 2020 and should be annually updated. The multilateral ambition of the EU was accompanied by human rights dialogue with UN, Council of Europe and other international forums. In this context, the European Union presented leadership ambition and remained committed to protect human rights and democracy through its external actions in the world.

Based on the recent report of 2017 which was assessing the EU actions based on the current Action Plan for 2015-2019, ${ }^{45}$ the EU is clearly more active in some of the areas than others. These include the equality and anti-discrimination area, in particular gender equality and fight against gender-based violence, protection of children and racism, racial discrimination, xenophobia and related intolerance. The report devoted detailed information on the EU actions related to freedom of expression and civil society, democracy and election, and human rights defenders. Last, but not least, mobility, migrants, refugees and asylum seekers were paid lot of attention from and efforts of the EU. In these areas, the EU invests millions of Euros in new programs and projects. It also publishes calls for proposals in order to involve partners from different sectors. Moreover, the EU works hard on promotion and sharing of best practices through different events. The report welcomes the update of Guidelines on the Rights of the Child, and continual implementation of the other guidelines that were adopted since $2008 .^{46}$ As the core mechanism, human rights dialogue is identified, through

41 Joint Communication 'Keeping Human Rights at the heart of the EU Agenda, JOIN (2015) 16 final. Available at: http:// eur-lex.europa.eu/legal-content/EN/TXT/PDF/?uri=CELEX:52015JC0016 \& rid=2 (accessed on $5^{\text {th }}$ November 2018).

42 Ibid., p. 4.

43 EU Annual Report on Human Rights and Demoracy in the World 2016, p. 4. Available at: https://reliefweb.int/sites/ reliefweb.int/files/resources/annual_report_on_human_rights_and_democracy_in_the_world_2016_.pdf (accessed on $5^{\text {th }}$ November 2018).

44 Ibid., p. 7.

45 EU Annual Report on Human Rights and Democracy in the World 2017. Available at: https://www.consilium.europa. eu/en/press/press-releases/2018/05/28/human-rights-and-democracy-in-the-world-eu-annual-report-2017-adopted/ (accessed on $5^{\text {th }}$ November 2018).

46 EU Guidelines on the Promotion and Protection of the Rights of the Child - Leave no Child Behind (2017); EU Human 
which the EU consults and communicates. In other areas, there is significant lack of action by the EU, especially in the area of human rights approach to conflicts and crisis.

\section{$4 \quad$ CONCLUSION}

Is the EU's power perception more determined by what the EU does rather what the EU is or vice versa? If we consider the position of the EU in area of protecting and promoting human rights in external relations, the answer is quite complicated. The EU in its founding treaties set the human rights as fundamental principle and values common for all member states. In relation to external action, the EU has ambition to play important role in the international area. One of the possible ways to act as international actor are human rights. The agenda of human rights is in external relations present in legal terms since 2009, when the Council adopted Conclusions on democracy support in the EU's external relations. As such, it is interconnected with democracy: "Human rights and democracy are inextricably connected. Only in democracy can individuals fully realize their human rights; only when human rights are respected can democracy flourish." ${ }^{\prime 7}$ For this purpose, the EU had adopted its own system of institutions and tools to protect and promote human rights in external relations.

Once evaluating this system, the existed documents as EU Strategic Framework and Action Plans on Human Rights and Democracy use to set the priorities of mid and long-term character. The applicable Action plans provide more space for the concrete actions and legislation. The institutionalization of the EU special representative for human rights had the ambition to provide "face" to EU human rights agenda. But to establish the system does not mean automatically the proper and effective implementation. As Mark Dawson said, “The new special representative's ability to make a difference will depend on going further: this representative should not be just an external voice for human rights but should be given internal powers too, for example the ability to scrutinize legislation or even recommend legal measures against states who persistently act in violation of the EU Charter. To be a credible "external" actor, the EU must also be credible in terms of its own human rights commitments." 48

Our analysis looked at particular instruments and actions the EU uses and conducts in the human rights policy in external action. We observed three criteria that are most suitable for our analysis - institutionalization, instruments and procedures, and consistency and coherence in the policy. The analysis of the EU position in the area of human rights and external relations confirms that the

Rights Guidelines on Freedom of Expression Online and Offline (2014); EU Guidelines on the promotion and protection of freedom of religion or belief (2013); Guidelines to promote and protect the enjoyment of all human rights by lesbian, gay, bisexual, transgender and intersex (LGBTI) persons (2013); EU Guidelines on Death Penalty: revised and updated version (2013); Guidelines to EU Policy towards third countries on torture and other cruel, inhuman or degrading treatment or punishment - an update of the guidelines (2012); EU Guidelines on promoting compliance with International Humanitarian Law (IHL) (2009); EU guidelines on human rights dialogues with third countries - update (2008); EU Guidelines on Children and Armed Conflict (2008); Ensuring protection - European Union Guidelines on Human Rights Defenders (2008); EU guidelines on violence against women and girls and combating all forms of discrimination against them (2008).

47 Council Conclusions of 18 November 2009 on democracy support in the EU's external relations, p. 6. Available at: http:// register.consilium.europa.eu/doc/srv?l=EN \& f=ST\%2016081\%202009\%20INIT (accessed on $5^{\text {th }}$ November 2018).

48 DEMPSEY, J.: Will an EU Special Representative for Human Rights Make a Difference? Available at: https://carnegieeurope.eu/strategiceurope/48818 (accessed on $5^{\text {th }}$ November 2018). 
EU by setting the institutional system and proper financial framework has the ambition to act as the human rights actor. On the other side, the implementation does not prove that the systematic approach based on financial support to achievement of human rights standards is an effective one. The EU solely by allocating more financial resources for human rights agenda in external relations proves rather to be defender and supporter of human rights, promoter of this fundamental principle, then to be human rights actor. Over time, the EU developed concrete mechanisms, especially the political and human rights dialogues that are used not only as a tool-kit, but also as a forum for presentation of the EU's vision of human rights and communication with third countries. The analysis of Action Plans shows that the EU is consistent and coherent only to certain extend, or only in certain areas. These areas refer to policies which have been developed internally, as they are also part of the EU internal functioning. However, when it comes to actions where the EU does not have its internal experience, i.e. human rights in conflict and crisis, the policy cannot be considered consistent or coherent, rather unfulfilled as the actions and tasks are continuously repeated. Nevertheless, the EU plan and vision is a stable basis for improvement in these areas. This includes better reflection of human rights reports and Council conclusion into the extension of competences of EU Special Representative for Human Rights. Human rights are a broad field and there are dozens of issues where the EU acts differently. However, applying comprehensive approach, there are clear shortages not only in planning, financing, but also in self-reflection of the EU itself. We therefore argue that the EU cannot be considered human rights actor, rather a supporter and promoter.

\section{Bibliography:}

AGGeSTAM, L.: A European Foreign Policy? Role Conceptions and the Politics of Identity in Britain, France and Germany. Doctoral dissertation. Stockholm: University of Stockholm, 2004.

ALLEN, D. - SMITH, M.: Western Europe's presence in the contemporary international arena. In: Review of International Studies, 16, 1990, 1, p. 19-37.

BINDI, F.: The Foreign Policy of the European Union. Washington: The Brookings Institution, 2010.

BRETHERTON, C. V:: The European Union as a Global Actor. London: Routledge, 1999.

BRETHERTON, CH. - VOGLER, J.: The European Union as Global Actor. London: Routledge, 1999.

BRETHERTON, CH. - VOGLER, J.: The European Union as Global Actor. $2^{\text {nd }}$ edition. London: Routledge, 2006.

BREUNING, M.: Role theory research in international relations. State of art and blind spots. In: HARNISCH, C. F. S.: Role Theory in International Relations. Approaches and analyses.London and New York: Routledge, 2011.

DEMPSEY, J.: Will an EU Special Representative for Human Rights Make a Difference? Available at: https://carnegieeurope.eu/strategiceurope/48818 (accessed on $5^{\text {th }}$ November 2018).

DUCHÊNE, F.: The European Community and the Uncertainties of Interdependence. In: KOHNSTAMM, M. - HAGER, W.: A Nation Writ Large? Foreign-Policy Problems before the European Community. London: Macmillan, 1973.

ELGSTRÖM, O. - SMITH, M.: The European Union's Role in International Politics. Concepts and Analysis. New York: Routledge, 2006.

GINSBERG, R. H.: The European Union in International Politics. Baptism by Fire. Boston, USA: Rowman \& Littlefield Publishers, 2001.

JUPILLE, J. - CAPORASO, J.: States, Agency and Rules: the European Union in Global Environmental Politics. In: RHODES, C. (ed.): The European Union in the World Community. Boulder, CO: Lynne Rienner, 1998.

MANNERS, I.: Normative Power Europe: A Contradiction in Terms? In: Journal of Common Market Studies, 40, 2002, 2, pp. 235-58. 
MANNERS, I.: Normative Ethics of the European Union. In: International Affairs, 84, 2008, 1, pp. 45-60.

McCORMICK, J.: The European Superpower. Basingstoke: Palgrave Macmillan, 2007.

MOGHERINI, F.: Shared Vision, Common Action: A Stronger Europe. The Global Strategy for the European Union's Foreign and Security Policy, 2016. Available at: https://eeas.europa.eu/archives/docs/top_stories/pdf/eugs_review_web.pdf (accessed on $5^{\text {th }}$ November 2018).

NIEMANN, A. - BRETHERTON, Ch.: Introduction: EU external policy at the crossroads. In: International Relations, Vol. 27, 2012, No. 3, pp. 261-275. Available at: https://international.politics.uni-mainz.de/files/2012/10/Niemannand-Bretherton_Special-edition_introduction_final.pdf (accessed on 5 ${ }^{\text {th }}$ November 2018).

RICHARD, Y. - VAN HAMME, G.: L'Union européenne, un acteur des relations internationales: Étude géographique de l'actorness européenne. In : L’Espace géographique, vol. 42, 2013, 1, pp. 15-30. Available at: https://www.cairn. info/revue-espace-geographique-2013-1-page-15.htm (accessed on $5^{\text {th }}$ November 2018).

SEDELMEIER, U.: The EU's role as a promoter of human rights and democracy: enlargement policy practice and role formation. In: ELGSTROM, O. - SMITH, M. (eds.): The European Union's Role in International Politics: Concepts and Analysis. Routledge/ECPR studies in European political science. London: Routledge, 2006, pp. 118-135.

SJÖSTEDT, G.: The external role of the European Community. Hamshire: Saxon House, 1977.

SMITH, K. E.: Still 'civilian power EU'? Working paper 1. Oslo: European Foreign Policy Unit, 2005. Available at: www.arena.uio.no/cidel/WorkshopOsloSecurity/ (accessed on $5^{\text {th }}$ November 2018).

WUNDERLICH, U.: The EU - A post-Westphalian actor in a neo-Westphalian world? Paper for presentation at the UACES Annual/Research Conference University of Edinburgh, 1-3 September 2008.

Council Conclusions on the mid-term review of the Action Plan on Human Rights and Democracy 2015-2019. Available at: https://www.consilium.europa.eu/media/21512/st12815en17-cc.pdf (accessed on $5^{\text {th }}$ November 2018).

Council Decision 2012/440/CFSP of 25 July 2012 appointing the European Union Special Representative for Human Rights, OJ L 200, 27. 7. 2012. Available at: http://data.europa.eu/eli/dec/2012/440/oj (accessed on $5^{\text {th }}$ November 2018).

Council Decision 2014/385/CFSP extending the mandate of the European Union Special Representative for Human Rights, OJ L 183, 24. 6. 2014. Available at: http://data.europa.eu/eli/dec/2014/385/oj (accessed on $5^{\text {th }}$ November 2018).

Council Decision (CFSP) 2015/260 of 17 February 2015 extending the mandate of the European Union Special Representative for Human Rights. OJ L 43, 18. 2. 2015.

Council Decision (CFSP) 2016/208 of 15 February 2016 amending Decision (CFSP) 2015/260 extending the mandate of the European Union Special Representative for Human Rights IO L 39, 16. 2. 2016, lch. 47-47. Available at: http://data.europa.eu/eli/dec/2016/208/oj (accessed on $5^{\text {th }}$ November 2018).

Council Decision (CFSP) 2017/346 of 27 February 2017 extending the mandate of the European Union Special Representative for Human Rights. OJ L 50, 28. 2. 2017. Available at: http://data.europa.eu/eli/dec/2017/346/oj (accessed on $5^{\text {th }}$ November 2018).

Council Decision (CFSP) 2018/225 of 15 February 2018 amending Decision (CFSP) 2017/346 extending the mandate of the European Union Special Representative for Human Rights. OJ L 43, 16. 2. 2018. Available at: http://data. europa.eu/eli/dec/2018/225/oj (accessed on $5^{\text {th }}$ November 2018).

Council Conclusions of 18 November 2009 on democracy support in the EU's external relations. Available at: http:// register.consilium.europa.eu/doc/srv?l=EN \& f=ST\%2016081\%202009\%20INIT (accessed on $5^{\text {th }}$ November 2018)

Council Conclusions of 18 November 2009 on democracy support in the EU's external relations. Available at: http:// register.consilium.europa.eu/doc/srv?l=EN \& f=ST\%2016081\%202009\%20INIT (accessed on $5^{\text {th }}$ November 2018).

EU's Strategic Framework and Action Plan on Human Rights and Democracy.

Available at: https://www.consilium.europa.eu/uedocs/cms_data/docs/pressdata/EN/foraff/131181.pdf (accessed on $5^{\text {th }}$ November 2018).

EU Action Plan on Human Rights and Democracy 2012-2014. Available at: https://www.consilium.europa.eu/uedocs/ cms_data/docs/pressdata/EN/foraff/131181.pdf (accessed on $5^{\text {th }}$ November 2018). 
EU Action Plan on Human Rights and Democracy 2015-2019. Available at: https://ec.europa.eu/anti-trafficking/sites/ antitrafficking/files/action-plan-on-human-rights-and-democracy-2015-2019_en.pdf (accessed on 5 ${ }^{\text {th }}$ November 2018).

EU Annual Report on Human Rights and Decmoracy in the World 2016. Available at: https://reliefweb.int/sites/reliefweb.int/files/resources/annual_report_on_human_rights_and_democracy_in_the_world_2016.pdf (accessed on $5^{\text {th }}$ November 2018).

EU Annual Report on Human Rights and Democracy in the World 2017. Available at: https://www.consilium.europa.eu/en/press/press-releases/2018/05/28/human-rights-and-democracy-in-the-world-eu-annual-report2017-adopted/ (accessed on $5^{\text {th }}$ November 2018).

EU Guidelines on the Promotion and Protection of the Rights of the Child - Leave no Child Behind (2017); EU Human Rights Guidelines on Freedom of Expression Online and Offline (2014); EU Guidelines on the promotion and protection of freedom of religion or belief (2013); Guidelines to promote and protect the enjoyment of all human rights by lesbian, gay, bisexual, transgender and intersex (LGBTI) persons (2013); EU Guidelines on Death Penalty: revised and updated version (2013); Guidelines to EU Policy towards third countries on torture and other cruel, inhuman or degrading treatment or punishment - an update of the guidelines (2012); EU Guidelines on promoting compliance with International Humanitarian Law (IHL) (2009); EU guidelines on human rights dialogues with third countries - update (2008); EU Guidelines on Children and Armed Conflict (2008); Ensuring protection - European Union Guidelines on Human Rights Defenders (2008); EU guidelines on violence against women and girls and combating all forms of discrimination against them (2008).

Joint Communication ,Keeping Human Rights at the heart of the EU Agenda, JOIN (2015) 16 final. Available at: http://eur-lex.europa.eu/legal-content/EN/TXT/PDF/?uri=CELEX:52015JC0016 \& rid=2 (accessed on 5 ${ }^{\text {th }}$ November 2018).

Joint Communication of the European Commission and EU High Representative for Foreign Affairs and Security Policy ,Human Rights and democracy at the heart of EU external action - Towards a more effective approach, COM(2011) 886 final, 12. 12. 2011. Available at: https://eur-lex.europa.eu/LexUriServ/LexUriServ. do?uri=COM:2011:0886:FIN:EN:PDF (accessed on $5^{\text {th }}$ November 2018).

Regulation (EU) No 235/2014 of the European Parliament and of the Council of 11 March 2014 establishing a financing instrument for democracy and human rights worldwide. OJ L 77, 15. 3. 2014.

\section{Contact information:}

Assoc. Prof. JUDr. PhDr. Lucia Mokrá, PhD.

lucia.mokra@fses.uniba.sk

Comenius University in Bratislava, Faculty of Social and Economic Sciences

Mlynské luhy 4

82105 Bratislava

Slovak Republic

Mgr. Kristína Janková, PhD.

kristina.jankova@fses.uniba.sk

Comenius University in Bratislava, Faculty of Social and Economic Sciences

Mlynské luhy 4

82105 Bratislava

Slovak Republic 